\title{
UPAYA MENINGKATKAN HASIL BELAJAR MATEMATIKA SISWA SMA MELALUI METODE KOOPERATIF TIPE THINK PAIR SHARE
}

\author{
Asmawaty \\ SMA Negeri 10 Batanghari Jambi \\ asmawatyjhon@gmail.com
}

\begin{abstract}
ABSTRAK
Tujuan penelitian ini untuk mengetahui apakah pembelajaran dengan menggunakan metode kooperatif tipe think pair share dapat meningkatkan hasil belajar siswa pada materi sistem pertidaksamaan linear dua variabel. Jenis penelitian adalah penelitian tindakan kelas. Subjek penelitian ini adalah siswa kelas XII. IPS. 1 SMA Negeri 10 Batanghari pada semester ganjil tahun pelajaran 2018/2019 yang berjumlah 23 orang. Penelitian dilaksanakan dari tanggal 23 Agustus 2018 sampai dengan 23 Oktober 2018. Tempat pelaksanaan di kelas XII.IPS.1 SMA Negeri 10 Batanghari. Penelitian dilakukan dalam dua siklus yang terdiri dari 4 tahap yaitu, perencanaan, pelaksanaan tindakan, obsevasi dan refleksi. Persentase nilai siswa, yang memenuhi KKM pada siklus I sebanyak 65,22\% dan siklus II sebanyak 78,26\%. Dapat disimpulkan bahwa pembelajaran dengan metode kooperatif tipe think pair share ini dapat meningkatkan hasil belajar siswa pada materi sistem pertidaksamaan linear dua variabel.
\end{abstract}

Kata kunci : hasil belajar matematika, think pair share

\begin{abstract}
The purpose of this study is to find out whether learning using the cooperative method type think pair share can improve student learning outcomes in the material of the two variable linear inequality system. This type of research is classroom action research. The subject of this research is class XII students. IPS. 1 SMA Negeri 10 Batanghari in the odd semester of the 2018/2019 academic year totaling 23 people. The study was conducted from August 23, 2018 to October 23, 2018. The place of implementation in class XII.IPS.1 SMA 10 Batanghari. The research was conducted in two cycles consisting of 4 stages, namely, planning, implementing actions, observing and reflecting. Percentage of student scores, which meet the KKM in the first cycle as many as $65.22 \%$ and the second cycle as many as $78.26 \%$. It can be concluded that learning using the cooperative method of the think pair share type can improve student learning outcomes in the system material in a two-variable linear equation.
\end{abstract}

Keywords : mathematics learning outcomes, think pair share 


\section{PENDAHULUAN}

Dalam kegiatan belajar-mengajar, berbagai macam masalah sering muncul dari siswa pada saat guru menyampaikan materi pelajaran. Berdasarkan pengalaman, proses belajar-mengajar di SMA Negeri 10 Batanghari ini masih belum bisa dicapai dengan maksimal, hal ini dipengaruhi oleh beberapa faktor seperti peran guru dalam kegiatan mengajar masih menggunakan metode ceramah, tanya jawab dan tugas saja, sehingga mengakibatkan siswa merasa bosan dan jenuh yang akhirnya membuat mereka tidak mengerti dan tidak memahami materi yang disampaikan termasuk mata pelajaran matematika. Dengan demikian hasil belajar siswa masih belum bisa mencapai KKM (Kriteria Ketuntasan Minimal) yaitu 71.

Rendahnya hasil belajar siswa serta kurangnya minat dan perhatian siswa terhadap materi pelajaran diduga disebabkan oleh penggunaan model pembelajaran yang diterapkan kurang tepat sehingga siswa kesulitan dalam menerima materi pelajaran dan siswa juga kesulitan dalam menyelesaikan tugas-tugas yang diberikan oleh guru serta siswa menjadi tidak termotivasi untuk dapat meningkatkan hasil belajarnya akibatnya sebagian besar nilai ulangan harian siswa di bawah standar.

Selama ini metode diskusi kelompok yang pernah dilakukan belum berjalan dengan baik karena belum terjadi interaksi yang baik antara sesama anggota kelompok pada saat berdiskusi, sehingga biasanya anggota kelompok selalu menyerahkan pada anggota kelompok yang lebih pintar diantara mereka untuk menyelesaikan tugas-tugas yang diberikan. Siswa atau anggota kelompok lainnya cenderung pasif dalam diskusi maupun pada saat menerima pelajaran yang disampaikan oleh guru.

Salah satu cara yang dapat dilakukan untuk mengatasi kendala-kendala yang dihadapi siswa di atas dapat dilakukan dengan pengubahan model pembelajaran, mencari model belajar yang membuat siswa tertarik untuk belajar. Untuk membuat siswa lebih memahami dan lebih mengerti tentang materi yang disampaikan, dicoba menerapkan model kooperatif tipe think pair share. Sehingga diharapkan siswa menjadi lebih aktif dan terampil, agar hasil belajarpun ikut meningkat.

Kegiatan dalam model pembelajaran kooperatif tipe think pair share terdiri dari tiga langkah (Arends dalam Trianto, 2011:82), yaitu : 1) Berpikir (Thinking); Guru mengajukan suatu pertanyaan atau masalah yang dikaitkan dengan pelajaran, dan meminta siswa menggunakan waktu beberapa menit untuk berpikir sendiri jawaban atau masalahnya. 2) Berpasangan (Pairing); Guru meminta siswa untuk berpasangan dan mendiskusikan apa yang telah mereka peroleh. Interaksi selama waktu yang disediakan dapat menyatukan jawaban jika suatu pertanyaan yang diajukan atau menyatukan gagasan apabila suatu masalah khusus yang diidentifikasi. 3) Berbagi (Sharing); Guru meminta pada pasangan-pasangan untuk berbagi dengan keseluruhan kelas yang telah mereka bicarakan. Hal ini efektif untuk berkeliling dari pasangan ke pasangan dan melanjutkan sampai sekitar sebagian pasangan mendapatkan kesempatan untuk melaporkan.

Melalui tiga langkah tersebut, model pembelajaran kooperatif tipe think pair share ini dapat melatih siswa berdiskusi dan mentransfer kembali pengetahuan yang diperolehnya ketika diskusi kepada teman lainnya. Hal ini dimungkinkan mereka untuk berpikir dan lebih aktif karena jumlah anggota kelompoknya yang cuma 2 orang. Artinya siswa dengan terpaksa harus berbuat, bekerja dan berpikir lebih keras karena tidak ada anggota kelompok lain yang bisa diandalkannya, selain itu mereka harus punya bahan untuk dijelaskan kembali kepada kelompok yang lainnya. 
Tujuan penelitian ini untuk mengetahui apakah pembelajaran dengan menggunakan metode Kooperatif Tipe Think Pair Share dapat meningkatkan hasil belajar siswa pada materi Sistem Pertidaksamaan Linear Dua Variabel.

\section{METODE}

Penelitian ini termasuk dalam jenis penelitian tindakan kelas (PTK). Menurut Suharsimi, dkk (2007) PTK merupakan kegiatan yang langsung berhubungan dengan tugas guru di lapangan. Artinya penelitian tindakan kelas merupakan tindakan praktis yang dilakukan di kelas dan bertujuan untuk memperbaiki praktik pembelajaran yang ada. Ciri utama dari penelitian tindakan kelas ini ada tindakan-tindakan yang dilakukan untuk memperbaiki dan menyempurnakan proses pembelajaran di kelas. Penelitian ini berupa penelitian partisipan dimana peneliti terlibat secara langsung dan penuh dalam penelitian mulai dari awal sampai akhir penelitian (Wiriaatmadja, 2008).

Penelitian dilaksanakan di kelas XII.IPS.1 SMA Negeri 10 Batanghari. Subyek penelitian adalah siswa kelas XII.IPS.1 SMA Negeri 10 Batanghari yang berjumlah 23 orang. Penelitian dilaksanakan dari tanggal 23 Agustus 2018 sampai dengan 23 Oktober 2018, yang terdiri dari dua siklus.

Prosedur penelitian ini disesuaikan dengan karakeristik penelitian tindakan kelas, yakni masalah yang harus dipecahkan dalam penelitian ini berasal dari persoalan praktik pembelajaran di kelas atau berawal dari permasalahan praktik faktual. Model penelitian tindakan kelas ini merujuk pada model Kemmis dan MC Taggart (1988) yang menguraikan bahwa tindakan yang digambarkan sebagai suatu proses yang dinamis dari aspek perencanaan, tindakan (pelaksanaan), observasi (pengamatan), dan refleksi.

Teknik yang digunakan dalam menganalisis data yang terkumpul adalah deskriptif kuantitatif dengan perhitungan persentasi kemampuan siswa dalam menjawab tes tertulis untuk mengetahui hasil sebelum dan sesudah dilakukan tindakan. Analisis data dalam penelitian ini melalui paparan data, dan penyimpulan hasil analisis. Menurut Slameto (2010) data tentang nilai hasil belajar (kognitif) siswa dihitung dengan menggunakan rumus sebagai berikut :

$$
\mathrm{NA}=\frac{\text { jumlah jawaban benar }}{\text { jumlah seluruh soal }} \times 100 \mathrm{I}
$$

Merujuk pada perhitungan tersebut maka penghitungan hasil tes siswa pada penelitian ini, digunakan rumus:

$$
\mathrm{NA}=\frac{\text { Jumlah Skor Perolehan }}{\text { Skor Maximal }} \times 100
$$

Sedangkan menurut Sudjana (2009) untuk mengetahui nilai rata-rata kelas pada masing-masing siklus digunakan rumus sebagai berikut :

$$
\bar{X}=\frac{\sum X}{N}
$$

Keterangan :

$\bar{X} \quad$ : Nilai rata-rata (mean)

$\sum X$ : Jumlah nilai seluruh siswa 


\section{$N \quad$ : Banyaknya siswa yang mengikuti tes}

Sedangkan untuk menentukan ketuntasan belajar secara klasikal, sesuai dengan Ali (2013) yaitu :

$$
\mathrm{P}=\frac{\sum n I}{n} \times 100 \%
$$

Keterangan :

$$
\begin{aligned}
& \mathrm{P} \quad \text { : Nilai ketuntasan belajar } \\
& \sum n I: \text { Jumlah siswa tuntas belajar secara klasikal } \\
& \mathrm{n} \quad \text { : Jumlah total siswa }
\end{aligned}
$$

Indikator keberhasilan dalam penelitian ini adalah ketuntasan siswa secara klasikal 75\% telah memenuhi KKM.

\section{HASIL DAN PEMBAHASAN \\ Siklus 1}

Siklus pertama dilaksanakan dalam satu kali pertemuan atau satu kali tatap muka, dengan lama waktu 2 jam pelajaran yaitu 90 menit. Tahapannya yaitu :

a) Perencanaan

Mengumpulkan data tentang hasil belajar siswa untuk menentukan tindakantindakan agar dapat meningkatkan hasil belajar siswa, menyusun Rencana Pelaksanaan Pembelajaran (RPP) yang digunakan pada siklus pertama dengan pokok bahasan Sistem Pertidaksamaan Linear Dua Variabel, mempersiapkan materi ajar yang akan disampaikan kepada siswa, mempersiapkan Lembar Kerja Siswa (LKPD) sebagai bahan untuk diskusi kelompok siswa, dan menyusun soalsoal tes untuk menilai hasil belajar siswa setelah dilaksanakan kegiatan pembelajaran dengan menggunakan metode kooperatif tipe think pair share ini.

b) Tindakan

Siklus pertama ini dilakukan ketika jam 1-2 di kelas XII.IPS.1 diawali guru masuk ke kelas. memberi salam kepada siswa, memperhatikan kehadiran siswa, memberikan penjelasan singkat kepada siswa tentang model pembelajaran yang akan digunakan yaitu metode kooperatif tipe think pair share. Apabila semua siswa paham mengenai teknis pelaksanaan metode kooperatif tipe think pair share lalu kegiatan pembelajaran dimulai, dengan menyampaikan tujuan pembelajaran.

Selanjutnya pembelajaran dimulai dengan pendahuluan yaitu melakukan apersepsi dengan beberapa pertanyaan selanjutnya memotivasi siswa untuk mengusai materi yang akan dibahas dan menyampaikan adanya keterkaitan materi yang akan dipelajari dengan materi selanjutnya.

Berikutnya kegiatan pembelajaran dilanjutkan dengan tahap kegitan inti, dimana guru menyampaikan materi tentang kompetensi dasar Sistem Pertidaksamaan Linear Dua Variabel. Pada saat pemaparan materi berlangsung, sebagian besar siswa tampak diam dan tenang mendengarkan serta memperhatikan penjelasan dari guru sementara sebagian lagi masih sibuk dengan aktivitas sendiri seperti mencari-cari pena, pensil, penggaris, buku dan ada pula yang masih asyik berbicara dengan teman di sebelahnya. Namun ada juga siswa yang aktif, dan 
beberapa siswa yang aktif setelah menyimak penjelasan dari guru ada yang langsung mencari contoh lain yang ada di buku paket yang mereka gunakan. Namun keadaan tersebut tidak berlangsung lama, karena beberapa menit kemudian mereka terganggu dengan siswa yang asyik bercerita dengan teman sebangkunya, hal ini kemungkinan karena pengaruh tempat duduknya di bagian belakang sekali dan mereka mengira guru tidak memperhatikannya, sebaliknya guru mengetahui hal itu dan guru langsung menegur hingga mareka kembali tenang dan memperhatikan.

Ketika proses pembelajaran berlangsung sesekali guru memberikan kesempatan kepada siswa yang ingin bertanya, namun pada awal kegiatan pembelajaran belum nampak ada siswa yang bertanya sehingga guru pun melanjutkan penjelasannya. Setelah penjelasan materi secara singkat kegiatan dilanjutkan dengan pembagian kelompok. Guru membagi siswa menjadi 11 kelompok kecil yang terdiri dari 2 orang untuk setiap kelompoknya.

Selanjutnya siswa diminta untuk duduk berdasarkan kelompok yang telah terbentuk, kemudian guru membagikan lembar kerja kepada setiap kelompok sebagai bahan diskusi mereka. Semua kelompok mengerjakan lembar kerja tersebut sesuai dengan intruksi, terlihat dalam setiap kelomok mereka berpikir bersama (berdiskusi) memecahkan atau menyelesaikan soal yang ada pada lembar kerja tersebut. Pada saat kerja kelompok guru berkeliling memperhatikan jalannya diskusi sambil membimbing kelompok yang kesulitan dalam pengerjaan LKPD. Hasil diskusi mereka satukan dalam lembar kerja kemudian dipresentasikan di papan tulis oleh beberapa kelompok yang ditunjuk. Guru memberikan waktu kepada siswa lain untuk memberi tanggapan dan di akhir diskusi guru memberi penguatan pada hal-hal yang penting.

Selanjutnya guru melakukan tes formatif pada akhir siklus. Tes ini dilakukan untuk mengetahui sampai dimana hasil belajar siswa dalam penguasaan materi pelajaran Sistem Pertidaksamaan Linear dengan menggunakan metode kooperatif tipe think pair share ini. Tes ini dilaksanakan $\pm 10-15$ menit. Di akhir kegiatan pembelajaran guru dan siswa bersama-sama menyimpulkan materi pelajaran yang telah dibahas. Guru memberikan penghargaan kepada siswa dan kelompok untuk keaktifan mereka selama proses pembelajaran berlangsung.

c) Observasi

Berdasarkan analisis hasil tes dari 23 orang siswa diperoleh nilai rata-rata tes formatif 1 sebesar 73.60. Siswa yang telah mencapai atau memenuhi KKM sebanyak 15 orang dan yang belum memenuhi KKM sebanyak 8 orang. Maka secara klasikal ketuntasan belajar yang telah tercapai sebesar $65.22 \%$, jadi secara klasikal dikatakan belum tuntas atau belum berhasil.

d) Refleksi

Berdasarkan hasil tes formatif 1 dari 23 siswa kelas XII IPS.1 yang mengikuti kegiatan pembelajaran, diperoleh 15 orang memenuhi KKM dengan persentase $65.22 \%$ dan 8 orang belum memenuhi KKM dengan persentase 34,78\%. Dari siklus pertama ini ditemukan beberapa kekurangan : 1) masih banyak siswa yang tidak memperhatikan gurunya menyampaikan materi, 2) masih ada siswa yang malu untuk bertanya pada guru tentang hal yang kurang dimengerti sehingga ketuntasan belajar masih rendah, 3) Masih banyak siswa yang tidak bertanggung jawab dalam melaksanakan tugas, 4) Masih ada siswa yang tidak mau menanggapi pendapat temannya dan tidak menyelesaikan hasil jawaban diskusi 
kelompoknya, dan 5) masih ada siswa yang hanya menyalin/mencontek pekerjaan temannya.

Dari kekurangan-kekurangan di atas maka dilakukan perbaikan-perbaikan dalam melaksanakan tindakan pada siklus selanjutnya seperti : 1) menegur dan memperingati siswa yang tidak mendengarkan atau tidak memperhatikan penjelasan guru pada saat kegiatan pembelajaran berlangsung, karena jika ada tingkah laku yang mengganggu ketenangan kelas, maka kemarahan dan teguran dari guru sangat berpengaruh. 2) memotivasi siswa untuk bertanya tentang hal-hal yang kurang jelas dan agar dapat mencatat penjelasan guru dan teman serta dapat menyelesaikan tugasnya masing masing dengan tanggung jawab. Hal ini sesuai pula dengan pendapat Hamalik (2005:120), salah satu upaya yang dapat dilakukan untuk meningkatkan kegiatan siswa adalah dengan pemberian dorongan lisan atau tertulis terhadap hasil pekerjaan siswa. 3) pada waktu kegiatan pembelajaran guru mengintruksikan agar mengerjakan LKPD mereka masing-masing, akan memotivasi siswa agar aktif dalam diskusi. Guru akan lebih mengarahkan dan memperhatikan agar siswa lebih mudah memahami atau lebih mengerti tentang materi yang dipelajari serta menegur siswa yang mencontek.

\section{Siklus 2}

Menindaklanjuti hasil refleksi, observasi dan pengumpulan data hasil belajar siswa pada siklus pertama, maka dilakukan tindakan siklus kedua agar dapat meningkatkan aktivitas dan hasil belajar siswa. Selanjutnya dilakukan tindakan perbaikan pada siklus kedua, dengan tahapan sebagai berikut:

a) Perencanaan

Mempersiapkan bahan ajar yang akan digunakan, mempersiapkan Lembar Kerja Siswa sebagai bahan untuk diskusi kelompok siswa, dan menyusun soal tes formatif 2 untuk menilai hasil belajar siswa.

b) Tindakan

Setelah itu guru memberikan materi tentang sistem pertidaksamaan linear dua variabel. Saat pemaparan materi berlangsung sebagian siswa tampak diam dan tenang mendengarkan serta memperhatikan penjelasan dari guru sambil sesekali ada beberapa siswa mencatat hal-hal yang penting yang guru jelaskan di depan kelas. Ketika pemberian materi berlangsung sesekali guru membuka waktu tanya-jawab untuk memberikan kesempatan kepada siswa yang ingin bertanya.

Kemudian guru membagi kelompok dan siswa telah duduk berdasarkan kelompoknya masing-masing, guru mengintruksikan untuk mengerjakan lembar diskusi tersebut. Merekapun berpikir bersama (berdiskusi) dengan kelompoknya masing-masing untuk menyelesaikan beberapa soal diskusi yang ada pada lembar kerja siswa. Gurupun membimbing siswa dalam pengerjaan LKPD tersebut. Setelah mengerjakan soal diskusi siswa menyatukan pendapat-pendapat mereka dan ditulis di lembar kerja mereka.

Melakukan tes pada setiap akhir siklus. Tes ini berguna untuk melihat adanya peningkatan nilai siswa setelah menggunakan metode kooperatif tipe think pair share ini, tes dilaksanakan $\pm 10-15$ menit. Selesai pemberian tes guru membimbing siswa bersama-sama menyimpulkan materi pelajaran yang telah dibahas. Setelah itu guru memberikan penghargaan kepada siswa dan kelompok berdasarkan peningkatan hasil nilai belajar sebelum siklus kedua dan keaktifan siswa selama proses pembelajaran berlangsung. 
c) Observasi

Berdasarkan hasil tes formatif 2 dari 23 orang siswa diperoleh nilai rata-rata sebesar 77,17. Siswa yang telah mencapai atau memenuhi KKM sebanyak 18 orang dan yang belum memenuhi KKM sebanyak 5 orang. Maka secara klasikal ketuntasan belajar yang telah tercapai sebesar 78.22 \% atau dapat dikatakan secara klasikal, pembelajaran telah tuntas atau telah berhasil. Pada siklus ini ada peningkatan ketuntasan belajar secara klasikal dari siklus I dan II sebesar 13,04\%. Adanya peningkatan hasil belajar pada siklus II ini dipengaruhi oleh adanya peningkatan kemampuan siswa dalam mempelajari dan menguasai materi pelajaran melalui model pembelajaran yang telah diterapkan, disamping itu juga dipengaruhi oleh kemampuan guru dalam mengelola proses belajar mengajar selama kegiatan pembelajaran berlangsung.

d) Refleksi

Berdasarkan hasil tes formatif 1 dari 23 siswa kelas XII IPS.1 yang mengikuti kegiatan pembelajaran, diperoleh 18 orang memenuhi KKM dengan persentase $78.26 \%$ dan 5 orang belum memenuhi KKM dengan persentase 21,74\%. Peningkatan jumlah siswa yang nilainya masuk dalam kateogri tuntas tentunya tak lepas dari peran guru dalam membenahi pembelajaran, mengoptimalkan usaha agar siswa dapat mengikuti pembelajaran dan memperoleh hasil yang memuaskan.

Kekurangan pada siklus 1 telah diperbaiki sehingga : 1) siswa yang tidak memperhatikan gurunya mengajar hanya segelintir orang, 2) siswa antusias bertanya pada guru tentang hal yang kurang dimengerti, 3) banyak siswa yang bertanggung jawab dalam melaksanakan tugas, 4) berkurangnya siswa yang tidak mau menanggapi pendapat temannya, 5) tidak ada siswa yang tidak menyelesaikan hasil jawaban diskusi kelompoknya, dan 6) tidak ada siswa yang hanya menyalin/mencontek pekerjaan temannya.

Hasil tes siswa pada pelaksanaan siklus 1 sebesar $65,22 \%$ yang tuntas dan pada siklus 2 sebesar 78,26\% yang tuntas, dengan demikian meningkat sebesar 13,04\%. Berdasarkan hasil tersebut indikator keberhasilan yang diharapkan yaitu $75 \%$ telah tercapai. Perubahan hasil belajar siswa setiap siklus terlihat pada tabel 1 berikut ini :

Tabel 1. Refleksi hasil tes formatif siklus 1 dan 2

\begin{tabular}{lccl}
\hline & Siklus 1 & Siklus 2 & Keterangan \\
\hline Jumlah siswa yang tuntas & 15 orang & 18 orang & Meningkat 3 orang \\
Jumlah yang belum tuntas & 8 orang & 5 orang & Turun 3 orang \\
Persentase ketuntasan & $65,22 \%$ & $78,26 \%$ & Meningkat 13,04 \% \\
Nilai rata-rata & 73,60 & 77,17 & Meningkat 3, 57 \\
Ketuntasan klasikal & Belum & Sudah & \\
& tuntas & tuntas & \\
\hline
\end{tabular}



ini :

Peningkatan hasil belajar siswa secara klasikal terlihat pada gambar 1 berikut

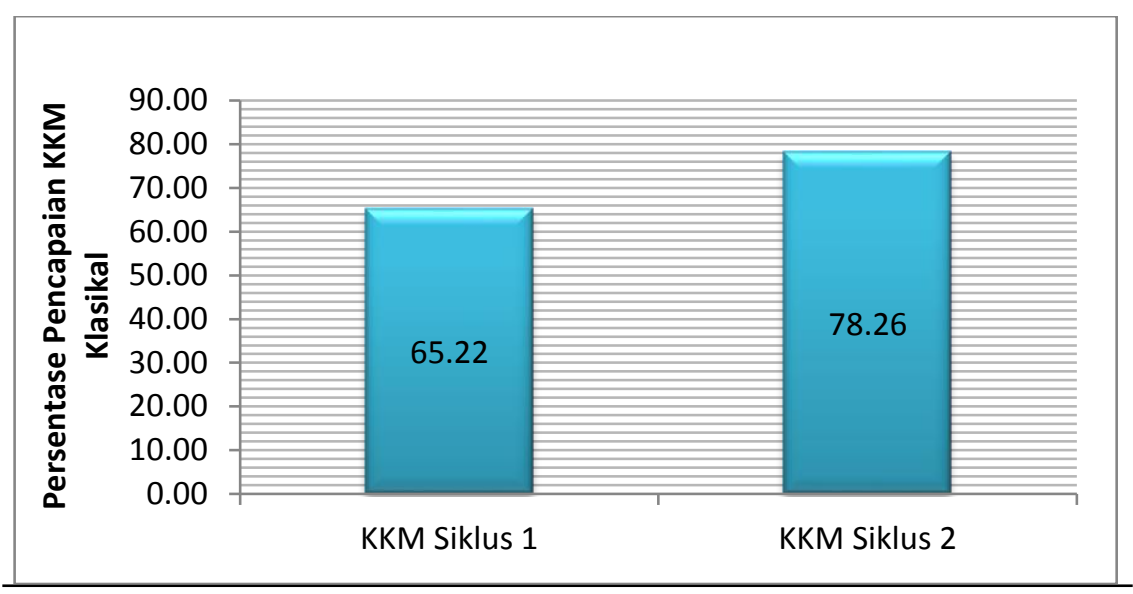

Gambar 1. Grafik pencapaian KKM klasikal

Pembelajaran dengan metode kooperatif tipe think pair share memang bagus diterapkan dalam pembelajaran di sekolah. Metode ini dapat membuat siswa untuk aktif, karena siswa bekerja hanya dua orang saja. Jika salah satunya tidak bekerja, tentunya temannya akan protes. Dengan dua orang yang bekerja saling mengisi dan saling membantu ini, rupanya membuat mereka merasa lebih bertanggung jawab terhadap tugas yang diberikan. Dengan demikian, hasil pekerjaan yang dicapai akan lebih maksimal.

Banyak juga penelitian serupa yang telah dilakukan siswa-siswa lainnya, misalnya penelitian yang dilakukan Ramdhani dan Murdiana (2015) menunjukkan bahwa penerapan model pembelajaran kooperatif tipe Think Pair Share dapat meningkatkan hasil belajar siswa kelas VIII SMP Negeri 3 Banawa pada materi persamaan garis lurus. Juga dari penelitian Nurhayati dkk (2018) menunjukkan bahwa penggunaan model pembelajaran kooperatif tipe TPS dengan pendekatan Quantum Learning menghasilkan prestasi belajar matematika lebih baik daripada model konvensional pada sub materi persamaan garis lurus. Dan masih banyak penelitian-penelitian lainnya yang menunjukkan keunggulan dari penerapan model pembelajaran kooperatif tipe think pair share.

\section{SIMPULAN}

Penelitian ini menghasilkan kesimpulan bahwa pembelajaran dengan metode kooperatif tipe think pair share dapat meningkatkan hasil belajar siswa kelas XII. IPS. 1 SMA Negeri 10 Batanghari pada materi Sistem Pertidaksamaan Linear Dua variabel.

\section{DAFTAR PUSTAKA}

Ali, M. 2013. Penelitian Kependidikan Prosedur dan Strategi. Bandung: CV. Angkasa.

Hamalik, Oemar. 2005. Proses Belajar Mengajar. Jakarta: Bumi Aksara.

Kemmis, S. and Mc. Taggart, R. 1988. The Action Research Planner. Victoria Dearcin University Press. 
Nurhayati, A., Usodo, B., dan Kuswardi, Y. 2018. Eksperimentasi Model Pembelajaran Kooperatif Tipe Think Pair Share (TPS) dengan Pendekatan Quantum Learning Ditinjau dari Gaya Belajar Matematika Siswa Kelas VIII Semester Gasal SMP Negeri 16 Surakarta Tahun Pelajaran 2013/ 2014. Jurnal Pendidikan Matematika dan Matematika SOLUSI, Vol. 2(3) : 221-230.

Ramdhani, N.F. dan Murdiana, I Nyoman. 2015. Penerapan Model Pembelajaran Kooperatif Tipe Think Pair Share Untuk Meningkatkan Hasil Belajar Siswa Kelas VIII SMP Negeri 3 Banawa Pada Materi Persamaan Garis Lurus. Jurnal Elektronik Pendidikan Matematika Tadulako, Vol. 2(3) : 294-304.

Slameto. 2010. Belajar dan Faktor-faktor yang Mempengaruhinya. Jakarta : Rineka Cipta.

Sudjana, Ibrahim. 2009. Penelitian dan Penilaian Pendidikan. Bandung: Sinar Baru Algesindo.

Suharsimi, A., Suhardjono, dan Supardi. 2007. Penelitian Tindakan Kelas. Jakarta: Bumi Aksara.

Trianto. 2011. Model Pembelajaran Terpadu. Jakarta: Bumi Aksara.

Wiriaatmadja, Rochiati. 2008. Metode Penelitian Tindakan Kelas. Bandung: Kerjasama Universitas Pendidikan Indonesia dan PT. Remaja Rosdakarya. 